\title{
Berries instead of bears: new insight into gastronomic attractiveness of Russian Siberia
}

\author{
Vladimir A. Ermolaev ${ }^{1}$, Dmitry A. Ruban ${ }^{2,3^{*}}$ and Natalia N. Yashalova ${ }^{4}$
}

\begin{abstract}
Active use of berries in regional cuisines underlines gastronomic specifics of Russia. The present study focuses on three regions of Russian Siberia and establishes that edible berries are numerous there and determine specifics of the regional cuisine rooted into the cultural traditions. These cultural and gastronomic traditions developed during four centuries by Russian settlers in Siberia who adapted to severe natural conditions, explored new food resources, and interacted with the local peoples. If so, berries and berry products can be regarded as a kind of ethnic food. Modern berries-based tourism (bacatourism) initiatives and, particularly, berry picking and tasting at you-pick farms and raspberry festival are registered on the study territory. Sellers tend to position berry products as typically Siberian, which permits their use as regional, quasi-ethnic souvenirs. Berries determine significant gastronomic attractiveness of Southern Siberia, and further exploitation of this potential can contribute to sustainable development of this vast territory and maintaining its cultural identity within the broad and diverse Russian space.
\end{abstract}

Keywords: Berry products, Cultural development, Ethnic tourism, Food tourism, Regional food, Russian history, Southern Siberia

\section{Introduction}

Since the ancient times, the development of the Russian society has been linked to peculiar gastronomic traditions, which are known only superficially and poorly-understood on the international level. One of these traditions is linked to active consumption of berries and berry products, which is rooted into the geographical and historical patterns of the country's growth. For some large regions like Southern Siberia, consumption of berries is a cultural peculiarity, which contributes to the regional identity (this is also a kind of ethnological pattern) and offers new opportunities for tourism and hospitality development (food products, especially those

\footnotetext{
*Correspondence: ruban-d@mail.ru

${ }^{2}$ K.G. Razumovsky Moscow State University of Technologies

and Management (the First Cossack University), Zemlyanoy Val Street 73, Moscow, Russia 109004

Full list of author information is available at the end of the article
}

regionally-specific are among the key determinants of tourism development [1]).

The objective of the present contribution is to provide the first characteristics of berries as a striking peculiarity of the regional cuisine and significant gastronomic tourism resource of Southern Siberia. Particularly, the attention is paid to the diversity of berries and the related products in three Russian regions, namely the Altai, Kemerovo, and Khakassia (Fig. 1), as well as to the relevance of berries to existing tourism initiatives and place branding. More generally, this paper aims at showing that Southern Siberia boasts not only dense forests, angry bears, and severe frosts, but also highly-interesting food traditions. In this regard, this study interacts with ethnological matters. It is essentially qualitative, which is linked to its pioneering character; nonetheless, a significant amount of factual information is taken into account for making well-argued judgments. original author(s) and the source, provide a link to the Creative Commons licence, and indicate if changes were made. The images or other third party material in this article are included in the article's Creative Commons licence, unless indicated otherwise in a credit line to the material. If material is not included in the article's Creative Commons licence and your intended use is not permitted by statutory regulation or exceeds the permitted use, you will need to obtain permission directly from the copyright holder. To view a copy of this licence, visit http://creativecommons.org/licenses/by/4.0/. 


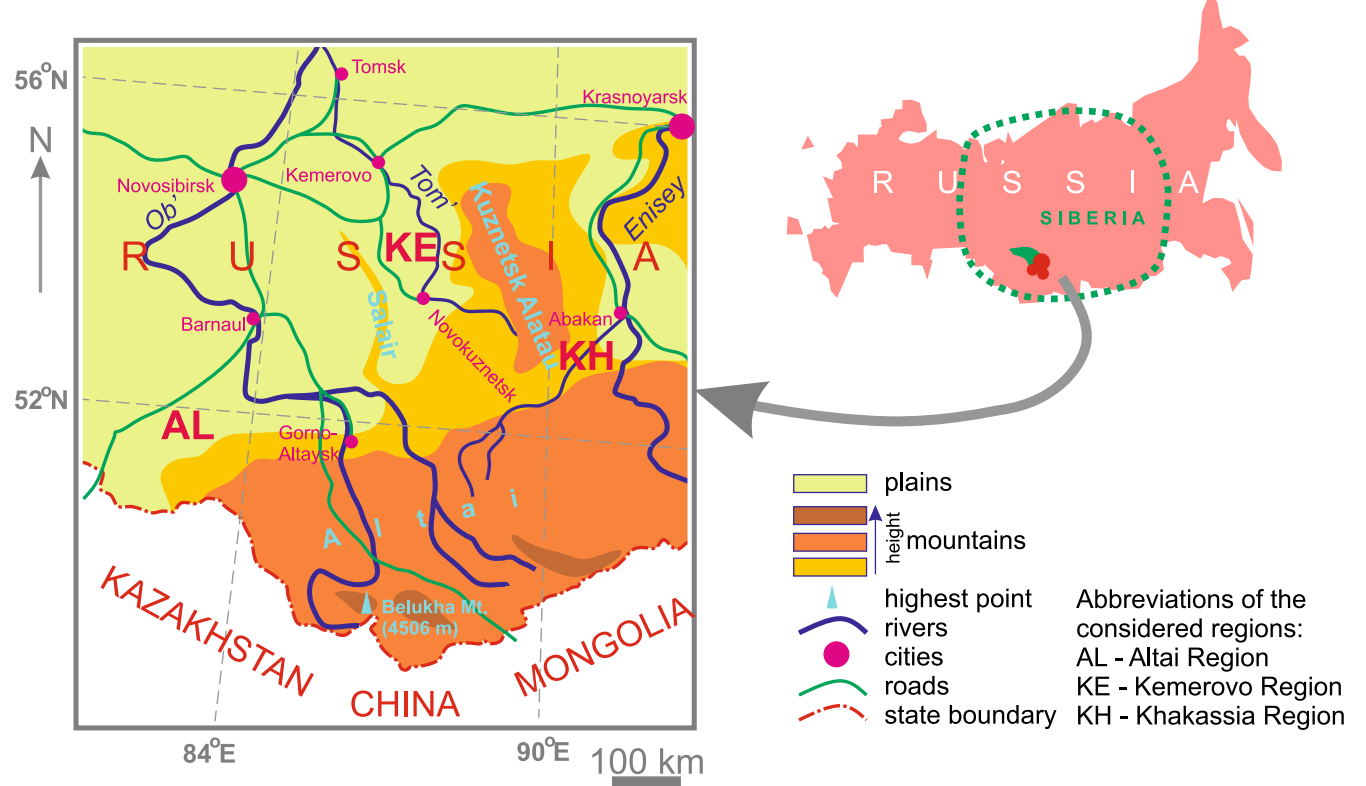

Fig. 1 Location of the berry-rich regions of Russian Siberia. Russian Siberia is a vast geographical domain (with the area of up to $13 \mathrm{mln} \mathrm{km}^{2}$ ) located between the Ural Mountains in the west, Far East mountain ranges in the east, the Arctic Ocean in the north, and the Russia-KazakhstanMongolia-China border in the south. Its western part is represented by lowlands, its eastern part is represented by highlands and plateaus, and its southern part is represented by impressive mountains like the Altai and the Sayany. All this area is densely forested, with spectacular wild life. Administratively, it belongs to the Siberian Federal District, and adjacent parts of the Ural and Far East federal districts. It populated chiefly in the south where the main cities and the main transport routes lie. Russian Siberia was populated by Russians moved from the west since the midst of the second millennium, although the local peoples have also remained there

\section{Geographical and historical background on berries in Russia}

Berries play important role in the Russian cuisine. According to Rosstat [2], the annual harvest of fruits and berries (these are not distinguished by the Russian statistics) reaches $3.5 \mathrm{mln} \mathrm{t}$, and it rose by 1.5 times since 2005 . About a half of this harvest is gathered in the central and southern parts of European Russia. However, one should that wild berries are harvested voluminously in the Russian Northwest and Siberia.

Berries are harvested in Russia in three general forms. First, these are cultivated at agricultural farms and by large agricultural corporations known as agroholdings. The latter sometimes include enterprises producing various berry products like jams and juices. Second, some farms allow local residents individual picking of specially cultivated berries. Such you-pick farms are popular, particularly, in Siberia. Finally, individual picking of wild berries in forests and at swamps is rather popular in some regions and allow local residents to couple collecting nutrient-rich food and outdoor recreation. These activities are popular in the forested domains of Russia, including northwestern and central part of European Russia and entire Siberia. In some cases, the volume of berries collected this way is so big that local residents offer their harvest to food enterprises for further industrial processing. Anyway, the majority of Russians prefers buying berries (dried or frozen) and berry products at various shops and markets for either direct consumption or further processing at kitchens.

Berries have become so important to the Russian cuisine, particularly, because Ancient Russia occupied densely-forested domain where berries constituted a unique food resource rich in nutrients, which can be conserved to be eaten during long and severe winters. The historical Russian societies are termed herbophilious [3]. The history of various berry products goes back to the very ancient times. For instance, kisel is a kind of berry jelly popular yet in the beginning of the 2nd millennium A.D., mors is a berry beverage known from the sixteenth century (at least), and varenye is a Russian handmade berry jam known from the very ancient times. The historical expansion of the Russian state to the south and the east facilitated geographical distribution of berry picking, eating, and processing traditions in the same directions. However, Russian settlers realized new kind of berries on new territories as well as cuisine traditions of the local peoples. In the Soviet times (1917-1991), harvesting berries industrialized, and, together with the advance of food processing technologies and logistics, 
this extended consumption of this nutrient-rich resource on the national scale. Additionally, cultivating berries has become more widespread than picking wild berries in forests.

In modern Russia, berries and berry products are very typical to the national cuisine, and they are appreciated on the level of individual households. One should note differences between the kinds of berries popular in different parts of the country. Moreover, berries remain relatively more popular in the same forested geographical domains like the Russian Northwest and Siberia where they retain high popularity as a food resource (Fig. 2).

\section{Study territory}

This paper focuses on the berries-related gastronomic attractiveness of Southern Siberia. Russia consists of 85 regions, and three of them can be considered as very typical representatives of Southern Siberia (Fig. 1). These are the Altai Region (area of $\sim 168$ thousands $\mathrm{km}^{2}$, population of $\sim 2.3 \mathrm{mln}$.), the Kemerovo Region (area of $\sim 96$ thousands $\mathrm{km}^{2}$, population of $\sim 2.7 \mathrm{mln}$.), and the Republic of Khakassia (area of $\sim 62$ thousands $\mathrm{km}^{2}$, population of $\sim 0.5 \mathrm{mln}$.). These are important destinations of domestic tourists, including gastronomic tourists: annually, hotels of the three considered regions host $\sim 1.5 \mathrm{mln}$. of guests [2].

Geographically, the study territory represents the 'core' of Eurasia, and it is rather complex (Fig. 1). It is dominated by mountain ranges, which include the Altai Mountains, the Abakan, Kuznetsk Alatau, and Salair ranges, and the Gornaya Shoriya Highlands. However, there are also vast Kulundinskaya and Fore-Altaian plains, as well as wide valleys of the big Abakan, Ob', and Tom' rivers and their tributaries. The climate is typically temperate continental, with long cold winters (the average January temperatures are $-19^{\circ} \mathrm{C}$, but they may drop below $-40^{\circ} \mathrm{C}$ ) and rather short, but warm (even hot) summers (the average July temperatures are $+18^{\circ} \mathrm{C}$, but they may exceed $+40^{\circ} \mathrm{C}$ ). The rainfall varies from $300 \mathrm{~mm} /$ year on plains to $>1000 \mathrm{~mm} /$ year in mountains. Deciduous, conifer, and mixed forests cover significant part of the study territory, although steppe (grassland) landscapes occur on plains and meadows cover some mountains. The dense forests are known as taiga.

Economically, the three considered regions differ: the Altai Region is one of the most important centres of agricultural production of Russia, the Kemerovo Region is a mining and industrial region, and the Republic of Khakassia specializes in hydroenergetics and heavy industry, as well as tourism. The density of population of these regions is moderate, but it is much higher than in entire Siberia. The biggest cities are Barnaul and Bijsk in the Altai Region, Kemerovo, Novokuznetsk, and Prokopievsk in the Kemerovo Region, and Abakan in the Republic of Khakassia. The transport infrastructure is well-developed, with a network of roads, railroads, and airports.

The population of the study territory is poly-ethnic. It is dominated by Russians (up to 90\%); the other peoples are represented by Altai peoples, Kazakhs, Khakassians, Shorians, etc. Khakassia is a national republic, where Khakassians constitute $>10 \%$ of the population.
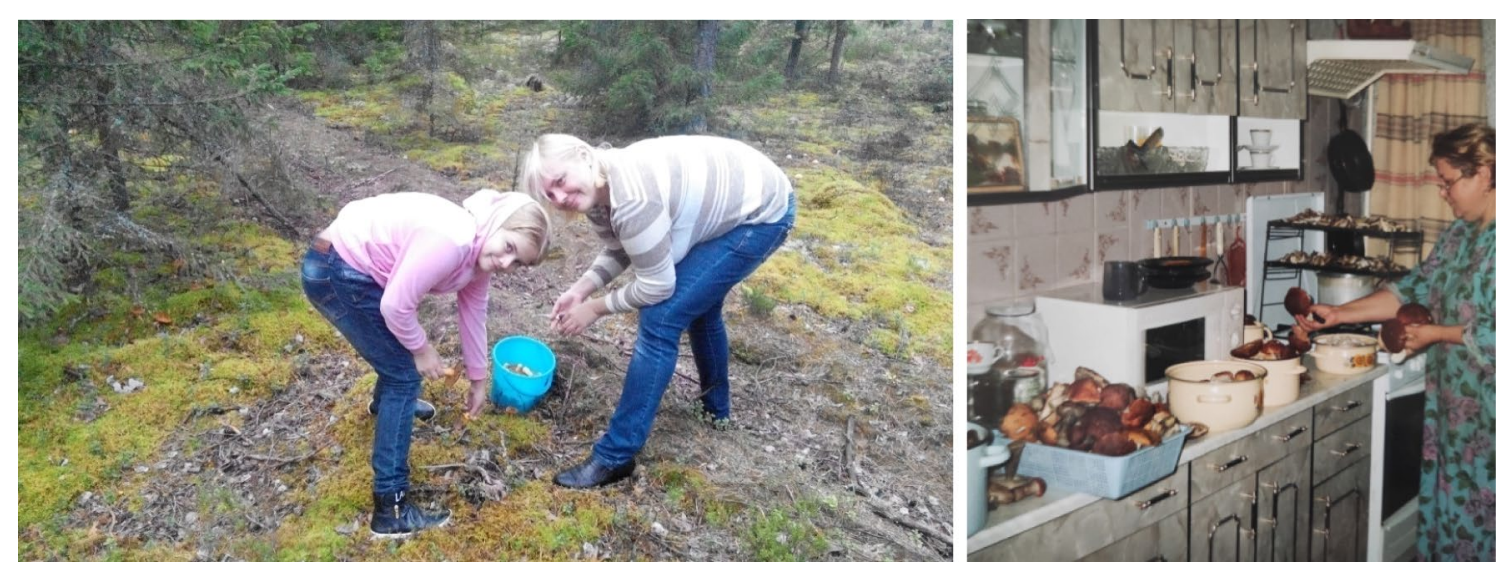

Fig. 2 Individual picking and then sorting berries, mushrooms, and other forest products in contemporary Russia. Like centuries ago, modern Russians actively visit forest for individual harvesting of various edible resources. After picking, these are brought to homes where sorted, dried, and conserved for further consumption during long winters. This remains essential for nutrients uptake in cold seasons. Such practices are especially typical to residents of the densely forested geographical domains of the Russian Northwest and Siberia. Although these practices share some characters of outdoor recreation (also for children), they are also customs reflecting the identity of the people living in the forested domains. In other words, picking berries, berries, mushrooms, and other forest products has remained a kind of regional, quasi-ethnic patterns inherited from the past, which can be judged characteristics to the Russian nation (or, at least, some of its major constituents) 
The first Russian settlements in Southern Siberia go back to the beginning of the seventeenth century when first forts were constructed. The purpose of these early settlements was protection of the Russian state from the peoples of Eurasian steppes; fur trade was also important. The exploration of the rich ore resources increased the state and entrepreneurs' interest in this area in the eighteenth century, and mining remained important industry for three centuries. Agriculture also grew. The regional cultural traditions were formed under the influence of several factors, namely dispersal of typically Russian culture, its modification in new environment characterized by more severe climatic conditions, finding new natural resources, lesser population density, and entrepreneural behavior of new settlers (bigger freedom, independency, and self-reliance of newcomers achieved to survive, but also to prosper), and contacts with the local cultures. The relevant patterns were investigated by historians and ethnologists, although the internationally-available works remain very few $[4,5]$.

\section{Materials and method}

For the purposes of this study, information of three categories is collected. First, the basic knowledge on edible berries available in Altai, Kemerovo, and Khakassia is synthesized. The attention is paid to nomenclature of berries, their geographical distribution, and harvest (season and productivity). The principal peculiarities of the regional consumption of berries are also outlined. Second, the existing berries-related tourism initiatives are identified. For this purpose, the information is gathered from the Russian segment of Internet via search by key words tourism/excursion/festival, berries, and Altai/ Kemerovo/Khakassia. The amount of this information is limited, and, thus, all recent initiatives are taken into account. Third, berry products can be treated as souvenirs, and, consequently, they can contribute to place branding. In Southern Siberia, these products are often sold by local producers or specialized shops. Ten most representative web-pages are examined in order to understand how these products are positioned. Particularly, the attention is paid to geographical affinity (regional, Siberian, or Russian) and relevance to the stereotypic Siberian nature (dense forests known as taiga) and regional cultural (food) traditions. Although the Internet information is preferred due to its outstanding importance to potential tourists [6-9], the observations of the first author who is a resident of the Kemerovo Region and his professional experience in the regional food industry are also taken into account.

The analysis of the collected information is qualitative and follows the general principles of qualitative research
[10-12]. The information is interpreted so to reach three particular goals, namely establishment of the diversity of edible berries and their relevance to the regional cuisine, registration of the actual presence of berries-related tourism in Southern Siberia, and evaluation of the importance of berry products to place branding.

\section{Regional products, traditions, and history}

Southern Siberia boasts outstanding diversity of berries, many of which are distributed in all three considered regions (Table 1 ). The majority of them are specially cultivated at farms, some of which function as you-pick farms. Although some of these berries can also be picked in forests as wild berries, the importance of this activity is relatively low. However, some berries are regionallyspecific and can be picked in the only forests of Khakassia (Table 1). The most important month for berry picking is August, although strawberry can be picked much earlier, and some berries can be picked in September.

Berries themselves and the relative products constitute an important resource for the cuisine of Southern Siberia. First of all, these are consumed in fresh state (soon after picking) and frozen/dry state (months after picking) (Fig. 3). Technologically, berries conservation is based on shock freezing and vacuum drying as the most common approaches. One should also note massive production of jelly powder (the latter is used for cooking the traditional Russian beverage called kisel that can be translated as jelly), berries-based beverages (Fig. 4), and jams and other products (Fig. 5). Additionally, there are locallyspecific products like berries mixed with honey.

All noted products are typical to both the modern cuisine of Southern Siberia and the regional culinary traditions, with berry cakes as a representative example (Fig. 5). When the Russian expansion into Southern Siberia started four centuries ago, the population of small and remote settlements surrounded by taiga forests recognized berries as important food resource (because of their richness in nutrients and flavor), which was used already by the local peoples. As a result, berries picking, conservation, and all-year consumption has become traditional activity and occupation for the whole families, and it has also formed significant peculiarity of the regional cuisine. This tradition has persisted until nowadays despite migration of the population form small and remote settlements to big cities. More generally, gastronomic traditions of Southern Siberia developed together with the regional cultural traditions outlined above. For instance, the abundance and the diversity of berries made them a food resource of outstanding importance for the Russian settlers. Their culinary use allowed to address the needs of nutrients and food diversification. The possibility to dry them effectively made them important for 
Table 1 Typical berries of Southern Siberia used in the regional cuisine

\begin{tabular}{|c|c|c|c|c|c|c|}
\hline \multicolumn{2}{|l|}{ Berry* } & \multicolumn{4}{|c|}{ Distribution (by regions) } & \multirow{2}{*}{$\begin{array}{l}\text { Harvest }^{* *} \\
\text { Productivity, } \\
\text { kg/10,000 m }\end{array}$} \\
\hline English (Russian ${ }^{* * *}$ ) name & Latin name & Altai & Kemerovo & Khakassia & Season & \\
\hline \multicolumn{7}{|c|}{$\begin{array}{l}\text { Cultivated berries (farms, includ- } \\
\text { ing you-pick farms) }\end{array}$} \\
\hline Lingonberry (Brusnika) & Vaccinium vitis-idaea & + & + & + & August & $100-140$ \\
\hline Blueberry (Chernika) & Vaccinium myrtillus & + & + & + & August & $80-120$ \\
\hline Currant (Smorodina) & Ribes & + & + & + & August & $100-130$ \\
\hline Bilberry (Golubika) & Vaccinium uliginosum & + & + & + & August & $100-120$ \\
\hline Strawberry (Klubnika) & Fragaria & + & + & + & June-August & $50-70$ \\
\hline Raspberry (Malina) & Rubus idaeus & + & + & + & August & $100-110$ \\
\hline Cranberry (Kljukva) & Vaccinium oxycoccos & + & + & + & August & $100-110$ \\
\hline Rose hip (Shipovnik) & Rosa & + & + & + & August-September & $5-12$ \\
\hline Ashberry (Rjabina) & Sorbus & + & + & + & September & $50-60$ \\
\hline Viburnum (Kalina) & Viburnum & + & + & + & August & $40-60$ \\
\hline Hawthorn (Bojaryshnik) & Crataegus & + & + & + & August & $5-15$ \\
\hline Cherry (Vishnja) & Prunus subg. Cerasus & + & & & August & 100 \\
\hline Blackberry (Ezhevika) & Rubus subgen. Rubus & + & & & August & 70 \\
\hline Gooseberry (Kryzhovnik) & Ribes uva-crispa & + & & & August-September & 30 \\
\hline Wild cherry (Chereshnja) & Prunus avium & + & & & August & 70 \\
\hline \multicolumn{7}{|l|}{ Wild berries (forests) } \\
\hline (Ozhika volosistaja) & Luzula pilosa & & & + & August-September & 10 \\
\hline (Ortilija) & Orthilia secunda & & & + & August-September & 10 \\
\hline (Badan) & Bergenia & & & + & August-September & 10 \\
\hline (Geran'sibirskaja) & Geranium sibiricum & & & + & August-September & 10 \\
\hline
\end{tabular}

Many of them are representatives of the genus Vaccinium, which is very abundant not only at farms, but also in wild state in the forests of the region. Significant diversity of berries is observed in the Altai, whereas some specific berries, the culinary use of which is only local, are found in Khakassia. Importantly, the harvest of the majority of berries is restricted on the only late summer, which makes their availability in fresh state only seasonal

* The present nomenclature of berries follows the Russian standard

** Based chiefly on the information from [13]

${ }^{* * *}$ Transliterated Russian names are provided to avoid any confusion with berry nomenclature

making food reserves for winter, when food was scarce and the transportation routes for obtaining it were blocked. The local peoples (for instance, Khakassians) actively used berries in their national culinary, and the related practices were easily accepted by arriving Russians. Such beverages as kisel and mors are typically Russian (Fig. 4), and they were not invented in Southern Siberia (see above). However, they received the 'second life' on this territory due to abundance of berries and their active use in culinary. Apparently, berries are not only important element in the regional cuisine of Southern Siberia, but their active use determine gastronomic peculiarities of this territory making it attractive to visitors interested in a new experience of food tasting.

\section{Tourism and positioning}

Russia hosts important tourists destinations like Saint Petersburg, Moscow, the Gold Ring, Lake Baikal, and Kamchatka, with $>20 \mathrm{mln}$ of international tourist arrivals visiting this country annually [14]. However, its potential for gastronomic tourism is significantly underestimated by both foreign and domestic visitors. The relevant, high-class research is lacking, with a few exceptions $[15,16]$. Filling this gap in the knowledge seems to be especially urgent because many Russian territories may attract significant tourist flows if they are able to diversify their tourism activities. Southern Siberia is rather densely-populated, boasts well-developed transport infrastructure, and hosts both natural and cultural heritage. Importantly, some regional gastronomic peculiarities link perfectly the stereotypic vision of this territory ('dense forests with bears and wolves') to the cultural traditions. For instance, berries are typical forest food, and their picking and conservation are common cultural practice in densely-forested domains. This is sufficient premise for consideration of berries-related activities as a new dimension of gastronomic attractiveness of Southern Siberia. 
a
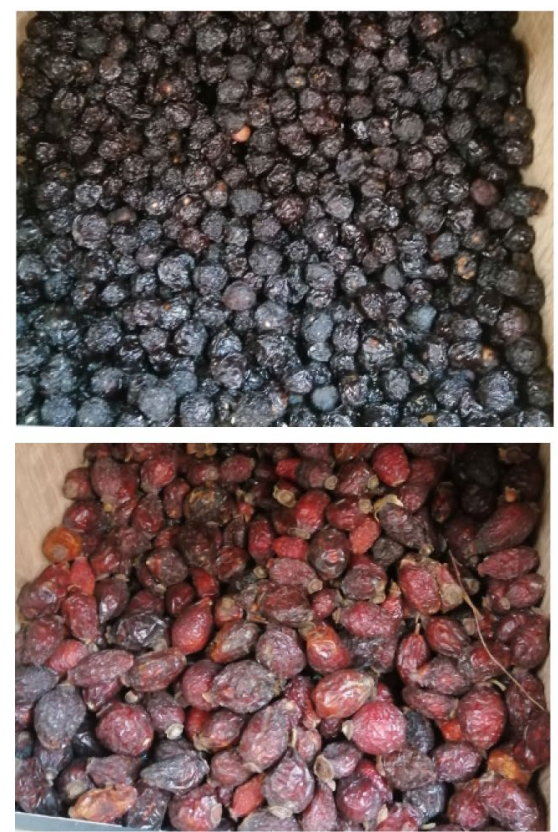

b
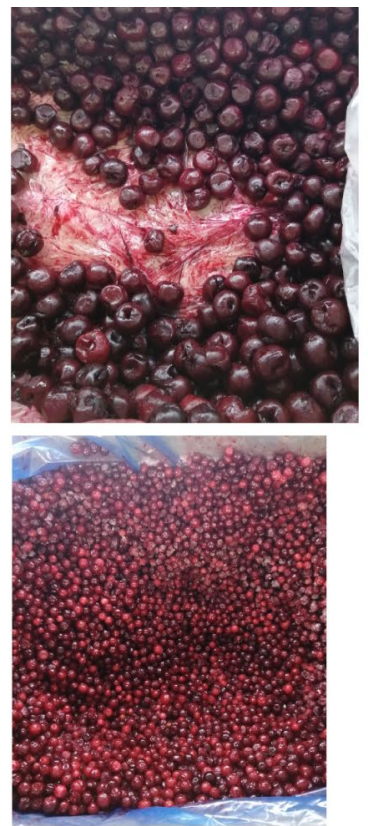

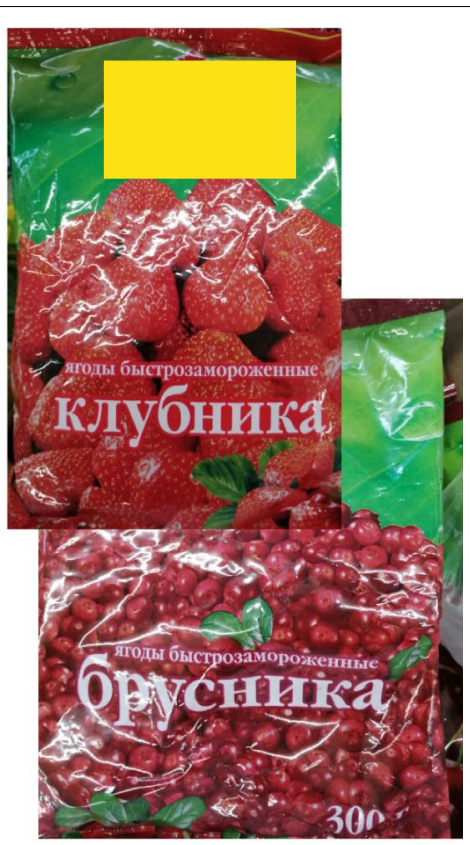

Fig. 3 Various states of conserved berries. a Dry berries; $\mathbf{b}$ frozen berries (producer names are closed to avoid occasional law violation). Berry harvest is very limited seasonally (Table 1), whereas the people prefer consumption of berries during the entire year, especially in winter when nutrients are demanded for health. This is why berries are either dried or frozen, which allow their conservation for months. In the past, conservation of berries was done individually, and this was an important summer occupation of Siberian families, especially living in remote areas. Presently, there are technologies that allow drying and freezing on industrial level, and such berries are widely sold by large stores and local vendors

The berries-related tourism initiatives in Southern Siberia are still few (Table 2). These include a local annual festival in a town with raspberry as its symbol, two excursions allowing picking berries in forests and at you-pick farm, and lengthy tours aimed at visiting several attractions and giving possibility to pick wild berries as a secondary-order recreation activity. Two most important initiatives, which represent the full-scale berries-related tourism in Southern Siberia, are the Art-Vishnja festival in Osinniki town of the Kemerovo Region and the garden excursion offered in the Republic of Khakassia. Undoubtedly, the collected evidence (Table 2) implies that the berries-related tourism in Southern Siberia is promising, but still needs development, especially in regard to the above-mentioned rich resources (Table 1).

The positioning of berry products demonstrates certain specifics (Table 3). First, much attention is paid to the Siberian affinity of these products, which is emphasized by $70 \%$ of the considered on-line sellers. The regional affinity is stressed more rarely, and the Russian affinity is mentioned in a single case. $40 \%$ of the sellers link berry products to forests, and surprisingly, their relevance to the local cultural tradition is found in the only case. This evidence means that the products are often positioned as a specific Siberian food, and, thus, these can be chosen as Siberian souvenirs with quasi-ethnic essence. However, their relevance to the particular regions, the stereotypic Siberian nature, and the regional cuisine is not demonstrated adequately. This is especially challenging because berries-related tourism initiatives can be offered only within a relatively limited season of berry picking, i.e., in summer (Table 1), whereas tasting berry products like frozen/dry berries, jams, kisel, etc. (Figs. 2, 3, 4 and 5), as well as buying them as souvenirs are possible on the annual basis.

\section{Discussion and conclusion}

The findings of this study need conceptualization and consideration in regard to their practical importance. The relevance of various berries to tourism has been discussed actively in the modern literature. The biggest attention has been paid to strawberry $[17,18]$. Less studied in this aspect are blackberry $[19,20]$, blueberry [21], cranberry [22], juneberry [20], and raspberry [21]. One would expect concentration of this research on temperate regions, but, in fact, practices and potential of berriesrelated tourism has been discussed for both temperate and tropical countries. Berries have already been used for the purposes of tourism. They serve for diversification of tourism activities, as well as for development of agritourism and rural tourism. Two main berries-related tourism activities are picking wild berries in forests and operation 

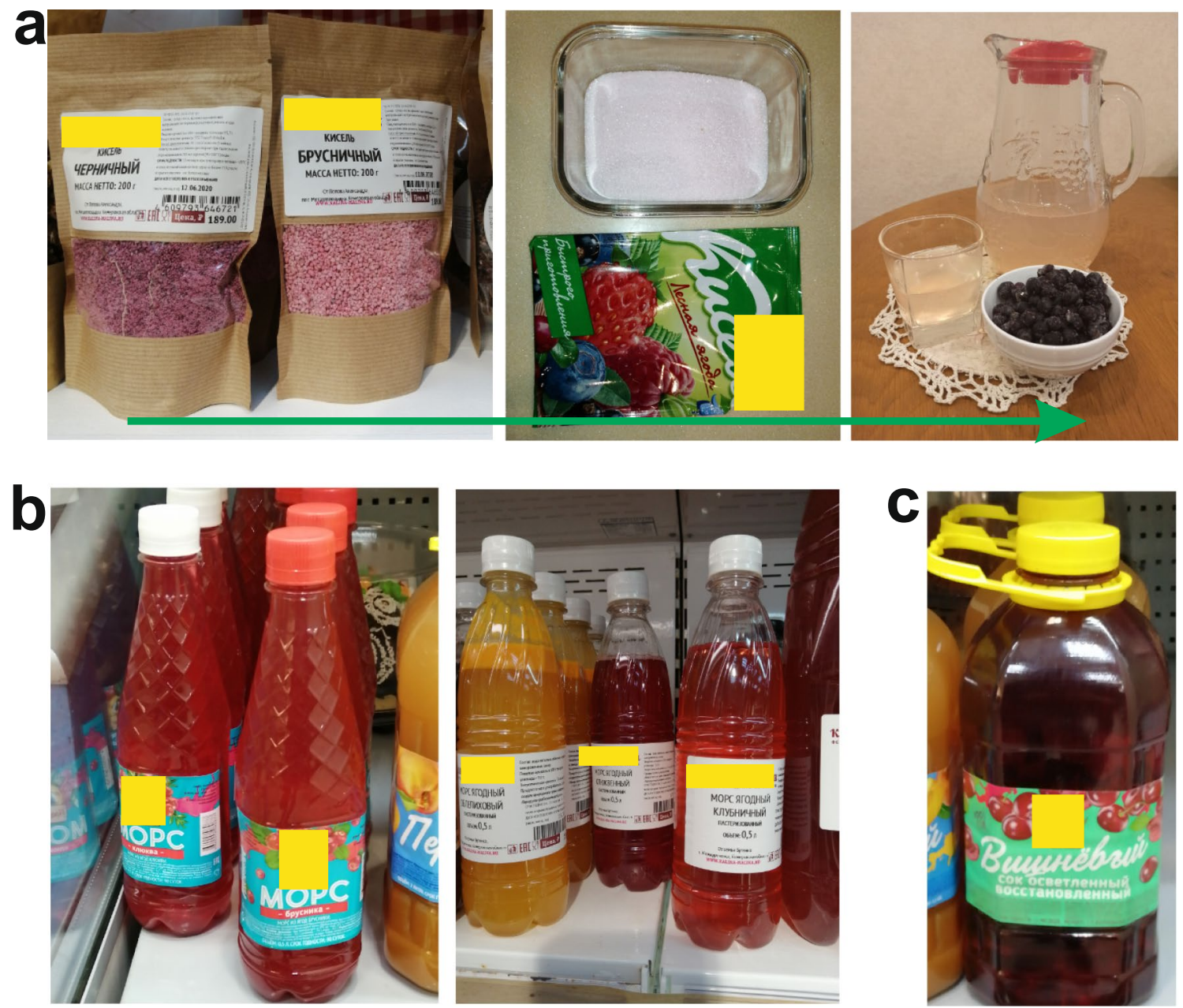

Fig. 4 Berries-related beverages (producer names are closed to avoid occasional law violation). a Kisel is a berry-based beverage very typical for the Russian and, particularly, Siberian cuisine. It looks like a dense, semi-transparent, jelly substance, which is rich in starch. It is preserved and sold as a dry powder prepared from starch and berries. After opening, it is mixed with water to obtain a jelly that can be drunk alone or with addition of fresh or dried berries. The green arrow on this figure indicates the direction of the kisel preparation procedure. Kisel is typically served either in winter (to provide the berries-related nutrients) or in hot summers as a cool beverage. $\mathbf{b}$ Berries are used for production of mors, another typically Russian beverage, which is essentially sweet berry juice with significant amount of water and sugar. c Common berry juices are also produced locally

of you-pick farms (also labeled as u-pick farms). The latter serve as both agricultural enterprises and recreational facilities. Additionally, berries-dedicated festivals can be attractive for tourists. Many published works are devoted to the general potential of berries as a tourism resource. Notably, the previous researchers in the Russian berriesrelated tourism [23-25] focused chiefly on its very general potential, not on actual practices, which indicates a serious research gap to be filled by new studies.

The literature evidence implies the both breadth and diversity of the berries-related tourism, as well as its active scientific investigation. This seems to be important premise to coin a special term for this tourism activity: the Latin word baca (berry) can be used to propose the term bacatourism for signifying all activities linked to usage of berries as a tourism resource, irrespective of whether these are purely recreational activities (berry picking), purely gastronomical activities (fresh/ dry/frozen berry tasting), or souvenir-related activities (buying berries and berry products as emblematic local food), especially because these activities are often interconnected. As berries constitute a food resource and their use diversifies cuisine practices, it seems to be logical to connect bacatourism to gastronomical tourism. Moreover, bacatourism is a subject of ethnological investigations. Berry picking and processing was important occupation of families of both Russian settlers and local peoples of Southern Siberia for centuries. This 

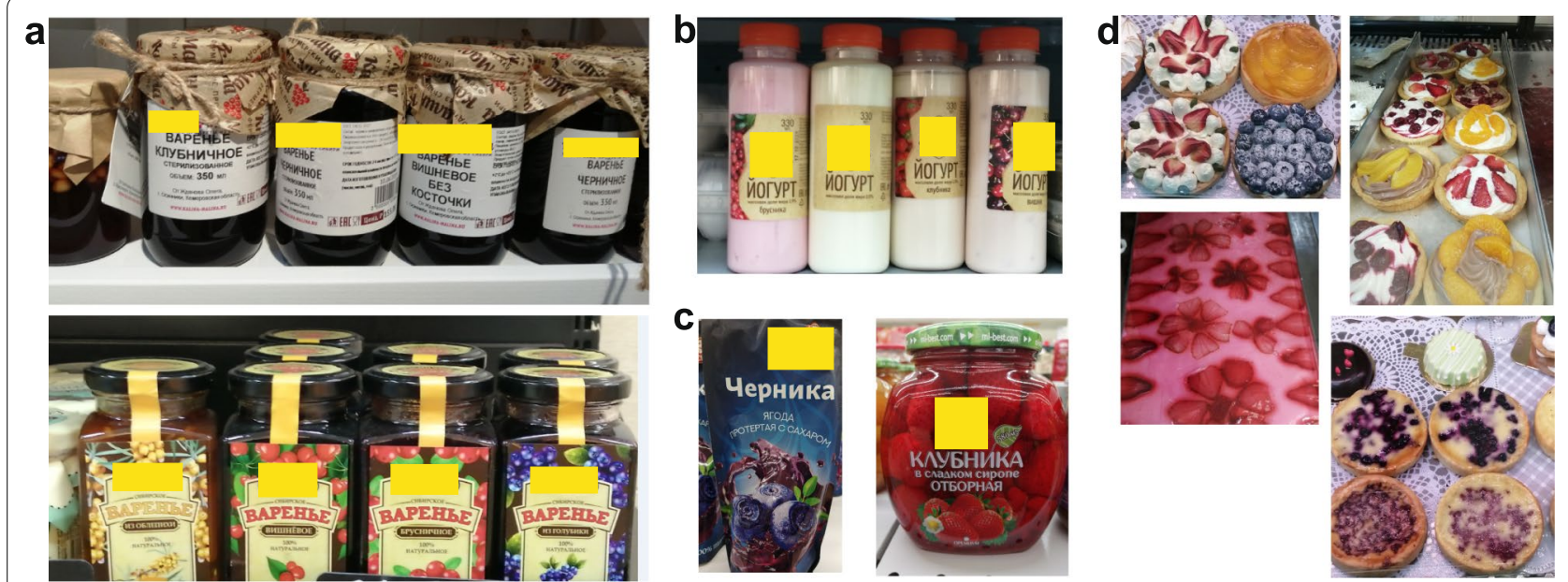

Fig. 5 Miscellaneous berry products (producer names are closed to avoid occasional law violation). Various berries-based foods are typical to the Siberian cuisine, and many of them are rooted into the local culinary traditions. a Jams; b Yogurts: c Berries mixed with sugar; $\mathbf{d}$ cakes. Some of these foods are produced by local food factories, but it is very common then they are made by hand at home by the local residents. So active use of berries in dessert culinary is inherited from the historical times, when berries were among very few natural products that allowed local residents (especially in remote, poorly-accessible forested areas) to diversify their cooking and to experience with new dishes

Table 2 Berries-based tourism initiatives in Southern Siberia

\begin{tabular}{|c|c|c|c|c|}
\hline Company/event & Region & Activity & Berries-related offer & URL (valid for November 2020) \\
\hline Art-Vishnja & Kemerovo & Cherry Fest & $\begin{array}{l}\text { Various activities linked to cherry-a } \\
\text { symbol of Osinniki town }\end{array}$ & http://artcherryfest.ru/ \\
\hline Sheregesh-Travel & Kemerovo & One-day excursion & Picking berries in forest & $\begin{array}{l}\text { http://sheregesh-travel.ru/services/excursions/furry- } \\
\text { friend-trekking-in-the-mountains.html }\end{array}$ \\
\hline Discovery & Khakassia & One-day excursion & Picking berries in a garden, tasting berries & $\begin{array}{l}\text { https://www.discovery-khakasia.ru/ekskursionnaya- } \\
\text { poezdka-v-abazu.html }\end{array}$ \\
\hline Domashnij otdykh & Khakassia & 11-day tour & Picking berries in forest near a lodge & https://www.hometravel.ru/ural/hakassia.shtml \\
\hline Viktorija & Khakassia & Tour & Tasting berries & $\begin{array}{l}\text { https://www.viktur.ru/regions/khakassia/tours-to- } \\
\text { khakassia-10182-1036.html }\end{array}$ \\
\hline Zapovedniki & Khakassia & 14-day tour & Picking berries in a garden & https://zapovedtours.ru/khakasiyatour2020 \\
\hline
\end{tabular}

These events and recreational activities are typical in the Kemerovo Region and the Republic of Khakassia. Importantly, they are strongly tied to local tourism programs, sometimes supported by the local governments. Although still few, they demonstrate a kind of diversity of bacatourism offer in Southern Siberia

occupation constituted routine practices of those who lived in or near taiga forests, and these practices are among the characteristic and even stereotypic features of the Siberian population.

The collected information implies that Southern Siberia boasts significant resources for bacatourism, but their exploitation is far from being extensive. The related initiatives are rare, and, particularly, you-pick farms that exist on the study territory serve chiefly for berry picking by the locals for personal consumption or re-selling in towns and cities. As for berry products as souvenirs, they are not positioned adequately in some cases. If even their Siberian origin is demonstrated, a visitor needs some geographical and historical knowledge to associate them with particular places. The knowledge for such interpretations may be almost absent in the case of foreign visitors.

Further bacatourism development opens new opportunities for Southern Siberia. The first of them is sustainable development of you-pick farms that depend chiefly on local consumers and weather-determined harvest in their present state. Their involvement into tourism initiatives would permit to increase and to diversify the demand for their production, as well as to make potential consumers aware of each given local producer. The second opportunity is linked to rural and ethnic tourism development in Southern Siberia, which can help to avoid degradation of rural communities and migration to cities with subsequent shortage of human resources in agriculture [26-30]. Moreover, bacatourism can 
Table 3 Positioning of berries-related products in the context of place branding

\begin{tabular}{|c|c|c|c|c|c|c|}
\hline \multirow[t]{3}{*}{ On-line seller } & \multicolumn{5}{|c|}{ Product positioning } & \multirow[t]{3}{*}{ URLs (valid for November 2020) } \\
\hline & \multicolumn{3}{|c|}{ Geographical affinity } & \multirow[t]{2}{*}{ Forest (taiga) } & \multirow{2}{*}{$\begin{array}{l}\text { Cultural } \\
\text { tradition }\end{array}$} & \\
\hline & Region & Siberia & Russia & & & \\
\hline Zdorovoe pitanie & & + & & & & https://kiseli-ru.com/ \\
\hline Privet iz Sibiri & & + & & + & + & https://hellofromsiberia.ru/about \\
\hline Sibirskie zemli & & + & & & & http://sibzemli.ru/ \\
\hline Kladovaja Altaja & + & & & & & https://www.instagram.com/altay.naturel/ \\
\hline Sibirskij produkt & & + & & & & https://sib-product.ru/catalog/ \\
\hline Dary Sajan & + & + & & + & & https://darysayan.wordpress.com/ \\
\hline Sladkij aromat & & + & & & & http://sladkiyaromat.ru/ \\
\hline Dary Khakasii & + & & & + & & https://ecosiberian.com/ \\
\hline Sibirskaja jagoda & + & & + & & & http://xn--80aabjfubq6aaagwke0ua.xn--p1ai/ \\
\hline Taiga Sibiri & & + & & + & & https://taiga-sibiri.ru/ \\
\hline
\end{tabular}

These products are often positioned as either typical Siberian or typical to a given region. Some of them brand taiga forests, which is a very stereotypical feature of Siberia. Surprisingly, the regional/local cultural traditions are mentioned in the only case, which indicates on a kind of disruption between the long-existing and very characteristic gastronomic traditions and the modern views of the relevant food products

contribute to conservation of traditions and culture of the study territory, which is important to support identity of both Russians and non-Russian peoples. The third opportunity is preservation and heritagizing of the regional food traditions and cuisine that are essential to maintain place identity [31-35]. Finally, correct positioning of berry products may help to make Southern Siberia more attractive to both domestic and foreign tourists because these products link the stereotypic vision of Siberia ('dense forests with bears and wolves') with its real cultural traditions and, particularly, its cuisine peculiarities. Practically, these opportunities mean that farmers, tourism industry managers, and regional/municipal administrations should turn their attention to the international experience of bacatourism for starting similar initiatives in Southern Siberia. Producers and sellers should improve positioning of berry products, with more attention to places, stereotypic nature attributes, and regional food traditions. These products need to reflect the identity of Siberian regions and stress the richness of their actual cuisine.

Conclusively, the present study reveals that Russian Siberia and, particularly, its southern regions can be attractive to visitors by their gastronomic specifics. Berries are in the core of the regional food traditions developed during four centuries of Russian persistence on this territory, and berry products serve as all-season souvenirs. These seem to be true ethnic food. The related tourism initiatives need diversification (particularly, coupling with ethnic and rural tourism development) for better attractiveness to potential visitors, and positioning of berry product requires better linking to geographical places and cultural traditions to contribute to their branding.

\section{Acknowledgements}

The authors gratefully thank the journal editors and the reviewers for their valuable suggestions, as well as E.M. Kazachkova (Russia) for her valuable linguistic advice.

\section{Authors' contributions}

Conceptualization-VAE, Data collection —VAE and DAR, Writing —DAR and NNY. All authors read and approved the final manuscript.

\section{Funding}

This paper is not based on any funded project.

Availability of data and materials

No data are associated with this paper.

\section{Declarations}

\section{Competing interests}

This paper is not a subject of competing interests.

\section{Author details}

${ }^{1}$ Department of Commodity Science and Expertise, Plekhanov Russian University of Economics, Stremyanny Lane 36, Moscow, Russia 117997. ${ }^{2}$ K.G. Razumovsky Moscow State University of Technologies and Management (the First Cossack University), Zemlyanoy Val Street 73, Moscow, Russia 109004. ${ }^{3}$ Department of Organization and Technologies of Service Activities, Higher School of Business, Southern Federal University, 23-ja Linija Street 43, Rostov-on-Don, Russia 344019. ${ }^{4}$ Department of Economics and Management, Business School, Cherepovets State University, Sovetskiy Avenue 10, Cherepovets, Vologda Region, Russia 162600.

Received: 16 November 2020 Accepted: 18 November 2021

Published online: 29 November 2021

References

1. Mak AHN, Lumbers M, Eves A. Globalisation and food consumption in tourism. Ann Tour Res. 2012;39:171-96. 
2. Rosstat. Regions of Russia. Socio-economical indicators. Moscow: Rosstat; 2019. ((in Russian))

3. Shikov AN, Tsitsilin AN, Pozharitskaya ON, Makarov VG, Heinrich M. Traditional and current food use of wild plants listed in the Russian Pharmacopoeia. Front Pharmacol. 2017:8:841

4. Hoerder D. Migration and cultural contact in the emergence of rus'-land, sixth to nineteenth centuries. J Migrat Hist. 2017;3:179-209.

5. Treivish Al, Litvinenko TV. Eastern Russia: space, role, and problems of development. Reg Res Russia. 2015:5:203-11.

6. Björk P, Kauppinen-Räisänen H. A destination's gastronomy as a means for holiday well-being. Br Food J. 2017;119:1578-91.

7. Luque-Martínez T, Castañeda-García JA, Frías-Jamilena DM, Muñoz-Leiva F, Rodríguez-Molina M. Determinants of the use of the internet as a tourist information source. Serv Ind J. 2007;27:881-91.

8. Rehman OU, Liu X, Rauf A, Slama MB, Amin W. Internet tradition and tourism development: a causality analysis on BRI listed economies. Tour Econ. 2020;26:926-57.

9. Vila TD, Vila NA, González EA, Brea JAF. The role of the internet as a tool to search for tourist information. J Glob Inf Manag. 2018;26:58-84.

10. Seale C. Quality in qualitative research. Qual Inq. 1999:5:465-78.

11. Shenton AK. Strategies for ensuring trustworthiness in qualitative research projects. Educ Inf. 2004;22:63-75.

12. Thelwall M, Nevill T. Is research with qualitative data more prevalent and impactful now? Interviews, case studies, focus groups and ethnographies. Library Inform Sci Res. 2021;43:101094.

13. Golub OV. Technological and practical aspects of studies of consumer properties of fruit-berry resource of West Siberia and products on its basis. D.Sci. thesis. Kemerovo: Kemerovskij tekhnologitchesij institut pitschevoj promyshlennosti; 2009 (in Russian)

14. UNWTO. International tourism highlights. Madrid: UNWTO; 2019.

15. Bukharov I, Berezka S. The role of tourist gastronomy experiences in regional tourism in Russia. Worldw Hosp Tour Themes. 2018;10:449-57.

16. Ermolaev VA, Yashalova NN, Ruban DA. Cheese as a tourism resource in Russia: the first report and relevance to sustainability. Sustainability. 2019:11:5520.

17. Aristya GR, Kasiamdari RS, Setyoningrum R, Larasati B. Genetic variations of strawberry cultivars of Fragaria $x$ ananassa and Fragaria vesca based on RAPD. Biodiversitas. 2019:20:770-5

18. Thongthieng T, Tongtraibhop P. Bio-extract in organic strawberry production of Amphoe Bo Kleua, Nan Province, Thailand. Acta Hortic. 2014;1049:719-22.

19. Conway MA, Samtani JB. Evaluation of blackberry cultivars in Virginia. Acta Hortic. 2016;1133:135-40.

20. Rousseau H, Bergeron D. Native plant development program. Acta Hortic. 2003;626:383-8.
21. Fachinello JC, Pasa MS, Schmtiz JD, Betemps DL. Situation and perspectives of temperate fruit crops in Brazil. Rev Bras Frutic. 2011;33:109-20.

22. Mezey J, Petrik M, Bajcan D, Harangozo L, Mezeyova I. Monitoring of heavy metals, bioactive substances and nutritional composition of cranberry (Vaccinium vitis-idaea) fruits in tatra national park forest ecosystem high-altitude transects. Inter Multidiscip Sci GeoConf Surv Geol Min Ecol Manag SGEM. 2019;19:761-8.

23. Evseev AV, Krasovskaya TM, Medvedkov AA. "Green" development of the Ugra territory: options and obstacles. Geogr Environ Sustain. 2017;10:94-102.

24. Raskovalov VP. Potential for recreational-commercial tourism in Perm Krai. Izv Rossiiskaya Akad Nauk Seriya Geogr. 2016;3:88-96.

25. Volkov SG, Sokolova ZE, Cherkasova OV, Prokhorenko OS. Development of northern rural areas: international and Russian experience. Int J Innov Technol Explor Eng. 2019;8:4375-80.

26 Aleksandrov IN, Fedorova MY. Digital economy and green economy: rura unemployment and territorial self-development in Russia. E3S Web Conf. 2019;110:02019.

27 Averkieva KV, Dan'shin Al, Zemlyanskii DY, Lamanov SV. Strategic Challenges of the development of agriculture in Russia. Reg Res Russia. 2017:7:322332

28. Bozhkov OB, Trotsuk IV. Tendencies of the Russian rural areas development: the research task and first results of the comparative casestudy. RUDN J Sociol. 2018;18:731-46.

29. Kurakin A. When the state is shirking: informal solutions for social services provision in Altai villages. Prz Wschod. 2015;6:145-59.

30. Nefedova TG, Pokrovsky NE, Treivish Al. Urbanization, desurbanization and rural-urban communities in the face of growing horizontal mobility. Sotsiol Issled. 2015:12:60-9.

31. Bessière J. 'Heritagisation', a challenge for tourism promotion and regional development: an example of food heritage. J Herit Tour. 2013;8:275-91.

32. Laing J, Frost W. Food, wine ... heritage, identity? Two case studies of Italian diaspora festivals in regional Victoria. Tour Anal. 2013;18:323-34.

33. Thomé-Ortiz H. Heritage cuisine and identity: free time and its relation to the social reproduction of local food. J Herit Tour. 2018;13:104-14.

34. Barrionuevo CA, Bernat EE, Velarde IJ. We recovered food heritage, and then? Value enhancement and promotion of local agri-food products in Argentina and Spain. Br Food J. 2019:121:3168-80.

35. Fuste-Forne F. Developing cheese tourism: a local-based perspective from Valle de Roncal (Navarra, Spain). J Ethn Foods. 2020;7:26.

\section{Publisher's Note}

Springer Nature remains neutral with regard to jurisdictional claims in published maps and institutional affiliations.
Ready to submit your research? Choose BMC and benefit from:

- fast, convenient online submission

- thorough peer review by experienced researchers in your field

- rapid publication on acceptance

- support for research data, including large and complex data types

- gold Open Access which fosters wider collaboration and increased citations

- maximum visibility for your research: over 100M website views per year

At BMC, research is always in progress.

Learn more biomedcentral.com/submissions 